\title{
THE ROLE OF INTERNATIONAL LAW IN A METROPOLITAN PRACTICE
}

\author{
Arthur H. Dean $\dagger$
}

Among the questions which large metropolitan law firms are being asked more and more frequently by law school students with an interest in international affairs is the place of international law in the firm's practice. Moreover, after many years of confining international law to the virtual limbo of a specialized course in "broad moral principles," of interest principally to the liberal arts student or the lawyer planning government service, many law schools have recently been reexamining their programs not merely in the area of public international law, but with respect to all the complex legal relationships across national boundaries.

Despite this awakening interest, misconceptions as to the role of international law in a big city practice persist not only among law students and some faculty members, but even among many practitioners. The two most prevalent ones are that lawyers specializing in international practice need only be trained in public international law and that for the general practitioner, a course in public international law is a luxury item rather than a staple.

\section{Limitations on a Specialized International Law Practice}

Even for the specialist in international legal problems ${ }^{1}$ public international law by itself is neither a sufficiently broad nor a desirable basis for a professional career as a practitioner.

In the first place, simon-pure public international law cases come along rather rarely in private practice. Specialization exclusively in such cases would, in general, not support an individual practitioner or occupy all the time of even a single specialist in a larger firm. The problem, moreover, is much more than the mere economic one of diversifying enough to earn a living. For even if it were financially possible

$\dagger$ A.B. 1921, LL.B. 1923, Cornell University ; LL.D., Allegheny College, Hamilton College; Member of the New York Bar. The substance of this Article was first presented in a speech before a joint meeting of the Committee on International Law of the American Association of Law Schools and the American Branch of the International Law Association, held in New York City on December 28, 1954.

1. With the possible exception of a member of the UN legal staff or a professor holding a chair in public international law and practicing as a consultant or lawyer's lawyer in that field. 
for a lawyer to devote himself in practice exclusively to public international law cases, such specialization would not, generally speaking, be in the best interests of the clients he represented or his own development as a lawyer. The proper handling of even pure public international law cases requires a rather broad and diversified experience in legal practice.

Possibly no cases encountered in private practice are more essentially international law matters than international claims cases. Yet one case under the Yugoslav Claims Agreement of $1948,{ }^{2}$ for example, involved a complex structure of holding companies above the Yugoslav corporation in which the claimants-consisting of no less than four trustees with a total of sixteen beneficiaries, two executors, and ten individuals-were stockholders. Familiarity with corporate law and with the law of trusts and estates was essential to the adequate presentation of the claim.

Secondly, not only is other legal learning applicable in cases involving international law matters, but many skills developed in purely domestic legal practice are immediately transferable and applicable to international law questions.

Any one familiar with the vast volume of corporate finance with which law firms representing large corporations and investment bankers deal, might wonder how an aspiring international lawyer with this type of firm can avoid such apparently unrewarding work as drafting a complicated corporate bond indenture. He probably can not, but he may well be a better international lawyer as a result of this "detour." Secretary of State Dulles has indicated that experience in negotiating and drafting just this type of complex legal document, making certain that the corporate borrower could live up to its exacting provisions, and obtaining the agreement of the lending institutions and corporate borrower to its final terms, was invaluable experience in negotiating, drafting, and obtaining the Senate's consent to the ratification of the Japanese Peace Treaty.

Thirdly, many matters which are popularly, and even among the profession itself, regarded as international law matters do not, technically, involve public international law at all, or at most only incidentally; rather they involve international conflict of laws, foreign law or the application of United States law to foreign clients and transactions. ${ }^{3}$

2. 62 STAT. 2658 (1948).

3. Accordingly, the international lawyer engaging in these fields requires not merely public international law training, but also courses in comparative and foreign law, particularly in learning such practical skills as how to find out what the foreign substantive law may be, the remedies for enforcing it, and how to prove such law in an American court. He may also require training in international conflict of laws over and above what he would receive in a conflicts course devoted mainly to the federal system, and some acquaintance with the United States constitutional principles 


\section{Utility of International Law in General Practice}

While there is often a tendency on the part of law students interested in foreign affairs to exaggerate the role of international law in private practice, by far the more prevalent tendency on the part of both practitioners and law professors, not all of whom are teaching competing courses, is to underrate both the scope and significance of its role. For technical competence in public international law is one of the essential tools of a lawyer engaged in a broad general practice in New York and other large cities in which representation of foreign clients and American clients with foreign investments or doing or planning to do business abroad is part of the daily legal fare.

Just as the absence of a broad legal background may result in the improper handling of international law cases, lack of really adequate training in public international law may result in the mishandling of, or the failure even to recognize, essential aspects of many of the problems arising in day-to-day practice. For unlike the Yugoslav Claims cases, most public international law problems arising in practice do not come all done up in blue ribbons and labelled "Public International Law," but arise in the context of complex factual situations involving other legal problems. Many specific examples can be given.

\section{Sovereign Immunity}

Certainly one of the most spectacular ways in which lack of international law training can betray the practicing lawyer is to neglect to point out to a client, who is entering into a contract with a foreign government or some agency of a foreign government, that the contract may not be enforceable in our courts if the foreign government chooses to plead sovereign immunity.

But, someone may protest, everyone knows that the doctrine of sovereign immunity exists. You do not have to be learned in international law to advise a client with respect to that.

It is not quite that simple. The whole scope of the doctrine of sovereign immunity has been undergoing reexamination ${ }^{4}$ since the announcement, in 1952, by the State Department that it would henceforth follow the restrictive theory of sovereign immunity and recognize

relating to international treaty and customary law, such as the supremacy of treaties of friendship, commerce, and navigation over state alien land laws, at least so long as Senator Bricker's "which clause" is not engrafted onto the Constitution. As to the reasons for the writer's opposition to the Bricker Amendment, see Dean, The Bricker Amendment and Authority over Foreign Affairs, 32 ForeIGN AFFaIRs 1 (1953); Dean, Amending the Treaty Power, 6 Stan. L. Rev. 589 (1954).

4. Republic of China v. National City Bank of N.Y., 23 U.S.L. WEEK 4111 (U.S. March 7, 1955). 
such immunity only in respect of sovereign or public acts, and not with respect to private acts of foreign governments.

Today, a lawyer's advice to a client with respect to the risk of nonenforceability of a contract with a foreign sovereign must take into account such questions as the extent to which the courts will follow the State Department in restricting sovereign immunity, what activities are in effect public or sovereign in nature, and the assessment of whether or not restrictions on the doctrine of sovereign immunity as applied to judicial proceedings will eventually also restrict the existing immunity with respect to the execution of judgments and seizure of the property of foreign sovereigns within the jurisdiction of the forum.

In advising a client in this area, a responsible practitioner should not limit himself to the reported American cases, but should certainly look at the State Department's expressed policy, the decisions and reasoning of courts in other countries which have been following the restrictive theory of sovereign immunity for many years, and the scholarly works in this field, such as the extremely helpful analysis contained in the Comments to the Draft Convention on Competence of Courts in regard to Foreign States drawn up by the Harvard Research in International Law with Dr. Philip C. Jessup as Reporter. ${ }^{6}$

It is not merely the commercial lawyers who have problems in this field. A few years ago, a banking client was asked to be escrow agent in connection with the settlement of a dispute between two foreign governments involving a substantial sum of money. Of course, we were concerned with the indemnity provisions with respect to its action or inaction under the terms of the escrow agreement. It would have been negligent indeed not to have advised the bank of the legal risk of nonenforceability of the indemnity in a United States court.

Similarly, the spectre of sovereign immunity hovers over the securities field. The Securities Act of 1933 requires that a registration statement with respect to securities issued by a foreign government or political subdivision thereof shall contain "the name and address of its authorized agent, if any, in the United States." 7 Furthermore, in practice, registration statements covering securities sold in the United States by a foreign government are normally signed by its authorized agent in this country, even though under the Securities Act they need be signed only by the underwriter of the securities. The question arises whether, by naming an authorized agent in a registration statement filed pursuant to the Securities Act of 1933 and having the

5. See letter dated May 19, 1952, of Jack B. Tate, Acting Legal Advisor, to the Acting Attorney General. 26 DEP'T STATE BuLr. 984 (1952).

6. 26 AMr. J. INT. L. Supp. 450 (1932).

7. 48 Stat. 91 (1933), 15 U.S.C. \$77aa Schedule B(7) (1952). 
authorized agent sign the registration statement, a foreign sovereign has consented to service of process on it through service on its authorized agent and effectively waived its sovereign immunity in so far as actions for enforcement of any liability or duties created by the Securities Act of 1933 are concerned.

Another interesting question is the extent to which the immunity of a foreign sovereign encompasses a private bank serving as its fiscal agent in this country. This was only recently the subject of extensive litigation in the courts of the State of New York ${ }^{8}$ as a result of actions brought against The Hanover Bank, as the fiscal agent of the Republic of Peru in connection with its 1953 offer of readjustment to the holders of its defaulted 1927 bond issue.

\section{Acts of State}

The post-war wave of nationalizations of the foreign property of American citizens has made the question of the validity under public international law of these nationalizations of very real concern to many general practitioners. This concern has not been limited to preparation for discussions with the State Department as to the possibility of obtaining adequate, prompt and effective compensation through diplomatic channels, or possibly through proceedings before the International Court of Justice, but also as to the type of legal action that could be taken in United States courts against importers into this country of products from a nationalized enterprise, such as oil taken from a nationalized concession area or refined in a nationalized refinery.

It may be urged that no such questions could ever be successfully raised in our courts because of the established doctrine of the Supreme Court that "Every sovereign State is bound to respect the independence of every other sovereign State, and the courts of one country will not sit in judgment on the acts of the government of another done within its own territory." 9

There is a very real question, however, whether that esteemed doctrine could withstand a determined and well-prepared legal attack grounded on the Supreme Court's established practice of applying international law "as often as questions of right depending upon it are duly presented for . . . determination." 10

8. See Frazier v. Hanover Bank, 204 Misc. 922, 119 N.Y.S.2d 319 (Sup. Ct.), aff'd, 281 App. Div. 861, 119 N.Y.S.2d 918 (1st Dep't 1953); see also Frazier v. Foreign Bondholders Protective Council, 283 App. Div. 44, 125 N.Y.S.2d 900 (1st Dep't 1953).

9. Underhill v. Hernandez, 168 U.S. 250, 252 (1897).

10. See The Paquete Habana, 175 U.S. 677, 700 (1900). 
The so-called act of state doctrine may well be limited to judicial abstention from questioning the validity, under United States law or policy ${ }^{11}$ or the local law of the foreign state, of the foreign government's acts within its own territory. There is very solid ground indeed for the position that until such time as the compulsory jurisdiction of the International Court of Justice is accepted by all nations, United States courts should not be foreclosed from determining the validity under international law of foreign acts of state in cases where the foreign sovereign or its agent is not before the court and a determination of the validity under international law of the foreign state's act is essential to the determination of the rights of the parties.

Such an inquiry would not be unprecedented. Justice Campbell of the Supreme Court of Aden found the Iranian Government's nationalization law invalid as related to nationalized oil coming within the jurisdiction of his court, and upheld the Anglo-Iranian Oil Company's title to oil sold to defendants by the Iranian Government. ${ }^{12}$ While the Italian courts apparently do not agree, ${ }^{13}$ there is considerable scholarly support for denying effect to an act of state of a foreign government invalid under international law. ${ }^{14}$

Recent decisions by the federal courts in this country have clearly established that not only is public international law the test to be applied in determining the effect to be given the acts of state of a military occupying government within the occupied territory ${ }^{15}$ but also the measure of the effect to be given the acts of the absent sovereign purporting to operate within the occupied territory. The case of State of the Netherlands v. Federal Reserve Bank of New York ${ }^{10}$ involved the applicability to the Netherlands during the German occupation of a royal decree of the Netherlands Government-in-Exile. This decree purported to vest protective title in the Netherlands Government to all securities belonging to persons domiciled in the Netherlands for the purpose of conserving the rights of the former owners. Counsel

11. Absent an explicit statement by the Executive relieving the courts of the restraint imposed by the act of state doctrine. Bernstein v. N. V. NederlandscheAmerikaansche, 210 F.2d 375 (2d Cir. 1954). See Note, 47 CoL. L. REv. 1061 (1947).

12. The Rose Mary, [1953] 1 W.L.R. 246.

13. Anglo-Iranian Oil Co. v. Societa Unione Petrolifera Orientale, 47 AMr. J. INT. L. 509 (Civil Tribunal of Venice 1953).

14. See Briggs, The Law of Nations 405 (2d ed. 1952); McNaIR, Legat EFFECTS OF WAR 322 (2d ed. 1944); Mann, International Delinquencies Before Municipal Courts, 70 L.Q. REv. 181 (1954); Morgenstern, Recognition and Enforcement of Foreign Legislative, Administrative and Judicial Acts Which Are Contrary to International Law, 4 INT'L L.Q. 326 (1951); Fachiri, Recognition of Foreign Law's by Municipal Courts, 12 BRIT. Y.B. INT'L L. 95, 103 (1931).

15. Aboitiz \& Co. v. Price, 99 F. Supp. 602 (D. Utah 1951).

16. 201 F.2d 455 (2d Cir. 1953), 53 CoL. L. REv. 561. 
for the Kingdom of the Netherlands were able to convince the United States Court of Appeals for the Second Circuit that the view of international law adopted by the district court ${ }^{17}$ - that no such enactment of an absent sovereign with respect to property in the occupied territory could be recognized-was incorrect and that the more persuasive international law precedents and authorities sustained the rule that the absent sovereign should be entitled to legislate with respect to the occupied territory in so far as such legislation did not conflict or interfere with the legitimate rule of the occupying power; it followed that the decree, far from interfering with the legitimate rule of the occupying power, merely implemented Article 46 of the Hague Regulations prohibiting confiscation of private property by the occupying power. ${ }^{18}$

\section{Recognition}

Still another type of problem which involves certain public international law considerations is that of advising a client as to the parties with whom he may safely deal as the representatives of a corporation incorporated under the law of a country of which the United States does not recognize the government, or as to which two separate competing governments exercise or purport to exercise jurisdiction, and, of course, the United States recognizes only one.

This problem existed from 1917 to 1933 with the Soviet Union and today, with the two governments of China. While cases involving this problem have frequently been litigated, for every case that has actually reached the courts there have been dozens of other instances in which lawyers have been called upon to advise clients as to the persons with whom they could deal with any assurance that any payment or settlement made would be binding on the foreign corporation.

Nor can sound advice be given in this field on the basis of a superficial knowledge or understanding. Suppose the case is one in which the foreign corporation is clearly an agency or instrumentality of the government recognized by the United States. In such a situation, a client may, in many situations, deal with considerable safety with the representatives of the government recognized by the United States. Even here there are degrees of risks, however. The client would probably be much safer if he pays, or settles with, the representatives of the recognized government in this country rather than abroad

17. State of the Netherlands v. Federal Reserve Bank of New York, 99 F. Supp. 655 (S.D.N.Y. 1951).

18. 36 Stat. 2307 (1910). 
and if, at the time of settlement or payment, he does not have any assets subject to attachment in another country which recognizes the other competing government.

If the corporation with which the client proposes to deal is not an agency or instrumentality of the recognized government but rather a private corporation, still more difficult legal questions are presented. To what law do we look in order to determine the authority of agents purporting to speak for the corporation in this country-the law of the recognized or the law of the unrecognized government? Does it make any difference if all the activities previously carried on by the corporation are presently carried on in territory controlled by the unrecognized government, and if the corporate activities of the officers and directors who are asking that the law of the recognized government be applied are limited to marshalling the extra-territorial assets of the corporation for the benefit of refugee stockholders?

Discussion of the substantive law on these very interesting points is beyond the scope of this Article. However, this general problem was raised in the litigation involving the Wells Fargo Bank \& Union Trust Company in the federal courts in California. The District Court for the Northern District continued the case sine die in 1950 rather than decide in favor of the competing Nationalist or Communist Chinese groups, each purporting to represent the Bank of China and to be entitled to its credit balance with Wells Fargo. In 1952, on remand from the court of appeals with the suggestion that the case be reexamined in light of changing world conditions and additional evidence, the district court gave judgment in favor of the Bank of China controlled by the Nationalist Government. ${ }^{10}$

\section{Extra-Territorial Effect of Local Law}

The possible role of international law in determining the validity of foreign acts of state taking effect within the territorial jurisdiction of the foreign state has been briefly explored. International law also now plays and may play a greater role in limiting the extra-territorial application of the law of a particular country.

Not so long ago the American practitioner might have shrugged off the relevance to his practice of this role of international law, resting on the proposition that our laws were territorial in operation, and our courts would similarly limit the legislative jurisdiction of foreign countries. If he were an antitrust lawyer, he might even have referred

19. Bank of China v. Wells Fargo Bank \& Union Trust Co., 92 F. Supp. 920 (N.D. Ca1. 1950), remanded, 190 F.2d 1010 (9th Cir. 1951), decided on remand, 104 F. Supp. 59 (N.D. Cal. 1952). 
to Justice Holmes' statement in the American Banana case ${ }^{20}$ that ". . . what the defendant did in Panama or Costa Rica is not within the scope of the statute . . .."

Today the antitrust lawyer may be more interested in any possible limitations on legislative jurisdiction which international law may impose. For he and his clients must take into account the efforts of the Antitrust Division of the Department of Justice to establish that the reference in the Sherman Act to United States "trade or commerce . . . with foreign nations" 21 should be construed to permit regulation of business conduct in any and all parts of the world, without regard for the laws, regulations or policy of the local sovereign, simply because such conduct may in some respect be deemed to "affect" our export or import trade. ${ }^{22}$

The so-called objective territorial theory of jurisdiction is all very well as applied to simple physical acts such as firing a gun across the frontier and killing a man in the other country and where the conduct with respect to which jurisdiction is exercised-i.e., murder-is condemned by the law and public policy of both jurisdictions. But the problem is quite a different one where the basis of the assertion of jurisdiction is the economic effect, however indirect, of business activity abroad on United States commerce, and the activity here attacked may be the only way of carrying on business in accordance with the laws, regulations and public policy of the territorial sovereign.

Thus, the only way to get import licenses, foreign exchange and allocations of railroad space in a particular country may be through a trade association. Market quotas and agreements on prices may be not merely permitted but required.

If the United States antitrust laws are applicable to such acts abroad in such circumstances, the businessman is faced with the unenviable choice of running the risk of being charged with violating the antitrust laws and of possible liability in the United States or, as an alternative, either violating the local law and policy of the foreign country in which he is operating or just getting out of business there at a time when our Government is attempting to encourage private investment abroad.

Customary international law has never in theory placed any restraints on a country's stujecting its nationals abroad to its own crim-

20. American Banana Co. v. United Fruit Co., 213 U.S. 347, 357 (1909).

21. 26 STAT. 209 (1890), as amended, 15 U.S.C. $\$ 1$ (1952).

22. The Ianham Act, 60 STAT. 427 (1946), 15 U.S.C. $\$ 1051$ (1952), regulating trademarks has also been applied extra-territorially. Steele v. Bulova Watch Co., 344 U.S. 280 (1952). 
inal law. ${ }^{23}$ Thus at least as far as United States nationals have been concerned, the question of applicability has been one of legislative intent and not of jurisdiction. Suppose, however, a country could under its own constitution, and did, make its traffic laws applicable to its citizens abroad. Then every time one of its citizens came to a country where he was required (both legally and for the safety of others as well as himself) to drive on the opposite side of the street from at home, he would violate his country's criminal law and be subject to prosecution for his crime when he went home. The example may be regarded as far-fetched because no legislature would ever dream of making its traffic laws applicable to its citizens abroad. Yet the extra-territorial application of the American antitrust laws daily presents American businessmen with equally poignant alternatives.

If Congress and the legislative bodies of other lands do not, themselves, restrict the territorial scope of their trade regulation laws, international lawyers may find it worthwhile to consider whether or not public international law's objective territorial and personal theories of legislative jurisdiction have not always been subject to the implicit limitation that the law of the absent sovereign should not be applicable where it would require conduct illegal or impolitic under the law of the territorial sovereign. ${ }^{24}$

Public international law also has to be taken into account when a question of the possible exercise of extra-territorial judicial or executive jurisdiction arises. Probably the most striking recent instance of this was in connection with the special grand jury investigation in Washington, $D$. C., of alleged world arrangements with respect to the production, transportation, refining and distribution of petroleum. Among the subpoena duces tecum served were those requiring the production of documents belonging to foreign corporations and held in foreign countries. However, the criminal proceedings involving the oil companies were discontinued before any decision was rendered on production of the documents held abroad, ${ }^{25}$ although in the interim, a number of foreign governments had registered objections to their production.

Attempts to secure compliance, in respect of business activities abroad, with the principles of the antitrust laws have not been confined

23. Blackmer v. United States, 284 U.S. 421, 437 (1932).

24. 1 Oppenheim, International Law 262-63 (7th ed. Lauterpacht 1948).

25. The subpoena served upon Anglo-Iranian Oil Company Limited was quashed, not because of the extra-territorial jurisdiction asserted, but because of a finding by District Judge Kirkland that Anglo-Iranian was an instrumentality of the Government of the United Kingdom and hence entitled to sovereign immunity. In re Investigation of World Arrangements with Relation to the Production, Transportation, Refining \& Distribution of Petroleum, 13 F.R.D. 280 (D.D.C. 1952). 
to actions against nationals of this country. Attempts have even been made to regulate the conduct abroad of foreign nationals over whom personal jurisdiction had been obtained in our courts. This has very naturally encountered resistance from foreign sovereigns. It was following the attempt on the part of the Antitrust Division of the Department of Justice to investigate Canadian pulp companies that the legislature of the Province of Ontario enacted the Business Records Protection Act forbidding the removal, except in certain stipulated circumstances, of any documents relating to any business carried on in Ontario in compliance with a subpoena or like order of a foreign authority. ${ }^{26}$ Attempts by the Antitrust Division to secure a judgment restraining the activities abroad of the Philips Lamp Company, a Netherlands corporation, over which personal jurisdiction had been obtained by service on one of its officials who had left Holland to escape from the Nazis, led to a protest by the Netherlands Government against an assumption of extra-territorial jurisdiction contrary to settled rules of international law. ${ }^{27}$

This opposition has not been limited to the legislative and executive branches of the foreign governments. The Chancery of the English Court of Appeal thought that the order of the United States district court in United States v. Imperial Chemical Industries, $L t d .^{28}$ asserted an extra-territorial jurisdiction which the English courts would not recognize notwithstanding the comity subsisting between civilized nations. ${ }^{29}$

26. Statutes of Ontario, Canada, 11 GEo. 6, c. 10 (1947), amended in immaterial respects, Statutes of Ontario, Canada, 14 GEO. 6, c. 7 (1947), as amended in immaterial respects, Statutes of Ontario, Canada, 14 GEo. 6, c. 7 (1950).

27. Note of May 3, 1951, from the Netherlands Ambassador to the Secretary of State. For a case in which the United States objected to the extra-territorial jurisdiction over an American citizen asserted by Mexico, see 2 MOORE, INTERNATIONAI, LAW Digest 228 (1906).

28. 105 F. Supp. 215 (S.D.N.Y. 1952).

29. British Nylon Spinners Itd. v. Imperial Chemical Industries Ltd., [1953] 1 Ch. 19 (C.A.). Imperial Chemical, an English corporation over which the United States district court had personal jurisdiction, had been ordered by that court to cancel an existing agreement with duPont de Nemours \& Co. and to reassign to duPont certain patents and rights therein previously assigned to Imperial Chemical for registration in the United Kingdom. Prior to the order of the district court, Imperial Chemical had entered into a contract in England with British Nylon Spinners, an English corporation not subject to the jurisdiction of the district court, to grant licenses under the duPont patents to Nylon Spinners within certain defined territories. At the date of the district court's order, Imperial Chemical had not formally registered the patents in the United Kingdom and no licenses had been granted to Nylon Spinners.

Nylon Spinners applied in the British courts and obtained an interlocutory injunction restraining Imperial Chemical from reassigning the patents to duPont in accordance with the United States district court's order. This injunction was continued by the Chancery Division on appeal.

Denning, L.J., concurring, did not read Judge Ryan's judgment in the district court as asserting extra-territorial jurisdiction "because although Imperial Chemical Industries has been ordered to do certain acts by the United States court, neverthe- 
It is, of course, difficult to state precisely what limits public international law at the present time sets on the legislative, judicial and executive jurisdiction of countries. But Brierly is certainly on sound ground in affirming that its primary function is "to define or to delimit the respective spheres within which each of the sixty-odd states into which the world is divided for political purposes is entitled to exercise its authority." 30 The working out of the detailed rules of international law to be applied in delimiting the jurisdiction of the various countries with respect to complex economic organizations and arrangements with contacts in more than one country would seem to be one of the most fruitful and important areas for scholarly research in public international law and one of the areas which an international law course designed for the practicing lawyer should stress most emphatically.

It is, of course, true that many of the existing limitations on the extra-territorial application of the local law of the particular state or the attempt to exercise judicial or executive jurisdiction in foreign countries may not have as yet hardened into rules of public international law but are grounded on the conflict of laws doctrine of comity. It may well be, therefore, that the international law course which will be most helpful to the practicing lawyer should not confine itself to public international law in the traditional sense, but should also concern itself to some degree with conflict of laws, or private international law as it is more appropriately denominated by our continental friends.

Of particular interest would be those areas in which private international law principles and doctrines differ from the conflict of laws rules applied among the various states of the United States and the shadowland between private international law and public international law where it is not clear whether the limitations on jurisdiction are merely principles of comity or grounded in public international law. ${ }^{31}$

A corollary to the role of public international law in delimiting jurisdiction and avoiding or minimizing conflicts among the national laws, courts, and executives of different sovereigns, is the possible further enhancement, particularly through international agreements, of its role in setting minimum substantive standards of conduct throughout the world. To the extent, for example, that the principles em-

less there is a provision which says that nothing in the judgment shall operate against the company for action taken in complying with the law of any foreign government or instrumentality thereof to which the company is for the time being subject." Id. at 28 . He did not mention the qualification to this saving clause, that it referred only to "matters over which under the law of the United States such foreign government or instrumentality thereof has jurisdiction."

30. Brierly, The Outlook for International Law 9 (1944).

31. Stevenson, The Relationship of Private International Law to Public International Law, 52 Cor. L. REV. 561 (1952). 
bodied in the Sherman Act are embodied in treaties requiring other sovereigns to implement these principles within their territorial jurisdictions, the American businessman will be subject to generally similar trade regulation laws abroad ${ }^{32}$ and at home, as, for example, is now generally the case in respect of American enterprises operating in Canada and subject to the Combines Investigation Act ${ }^{33}$ and related sections of the Criminal Code of Canada. ${ }^{34}$

A preliminary, tentative and controversial approach to the problem of establishing such general limitations on restrictive business practices was made in the recent Report, which has received very little public discussion, of the Ad Hoc Committee on Restrictive Business Practices to the United Nations Economic and Social Council, ${ }^{35}$ proposing the adoption of a multilateral international agreement in respect of such practices. On March 28, 1955, the United States Government advised the Secretary General of the United Nations of its view that the differences in national practices and policies in the field are so great that the proposed agreement would be "neither satisfactory nor effective" in eliminating restrictive business practices. ${ }^{36}$

Many of the recent bilateral commercial treaties into which the United States has entered provide for consultation with respect to business practices restraining competition, limiting access to markets or fostering monopolistic control, and for such remedial action as the respective governments may deem appropriate with a view to eliminating the harmful effects of such practices on commerce between their respective territories. ${ }^{37}$

Some grasp of the legal possibilities of and limitations on the growth of the substantive side of international law through general and special international agreements would seem to be necessary equipment not only for the antitrust lawyer, but for any lawyer whose clients' interests may be affected by the obligations assumed by the United States or other sovereigns. Some familarity, moreover, with the various international agencies already established by international agreement, such as the International Fund and International Bank, is becoming increasingly necessary for the general practitioner whose clients may, for example, be concerned with exchange restrictions or the pos-

32. Though not necessarily equally aggressive enforcement machinery.

33. CAN. Rev. Stat. c. 26 (1927), as amended.

34. $I d$. c. $36, \S \S 496,497,498,498 \mathrm{~A}$, as amended.

35. U.N. Economic and Soctal Council Off. Rec., 16th Sess., Supp. No. 11 (Doc. No. E2380) (1953).

36. 32 Dep't State Bull. 665 (1955).

37. E.g., Treaty of Friendship, Commerce and Navigation Between the United States of America and the Italian Republic, Feb. 2, 1948, art. XVIII(3), 63 STAT. 2255 (1949), T.I.A.S. No. 1965 (effective July 26, 1949). 
sibility of purchasing the securities of a foreign issuer guaranteed by the International Bank.

\section{CONCLUSTON}

This Article has, of necessity, been devoted to substantive problems with which the writer has personally been concerned. It has seemed to the writer that the role of international law in a metropolitan practice could be portrayed more graphically by a somewhat detailed discussion of actual problems and situations rather than a mere catalogue of cases in which international law has been involved.

Other specific examples of international legal practice, taken at random from the writer's own experience, include: the question of the effect of the Dawes Plan, which imposed a floating lien on all property in Germany, on the designation of German bonds as First Mortgage Bonds; the effect of Soviet nationalization decrees and the depreciation of the ruble on insurance policies issued by the Russian branch of an American insurance company and on the bank deposits in Russia of a French bank; the 1927 Plan of Financial Stabilization of Poland; the reorganization of the Mexican Light, Heat and Power Company and the loan to it by the International Bank guaranteed by the Republic of Mexico, including such problems as the effect of the various covenants in the loan agreement on its internal rate structure and the effect of devaluation of the peso on the rate of return on invested capital; the working out of open-end public utility mortgages effective under both civil and American law; problems arising under the freezing and vesting programs administered by the Treasury Department and the Alien Property Custodian under the Trading with the Enemy Act; questions arising in connection with the postwar settlement of the German and Japanese external debts and the establishment of validation procedures for certain German bonds; and the Iranian oil settlement.

The range of cases and problems involving international law to a greater or lesser degree, with which other lawyers are confronted, has by no means been exhausted. For example, no reference has been made to the international law aspects of the admiralty, civil aviation and copyright and trade-mark practices of many firms. Nor has mention been made of the many nationality and immigration questions with which every lawyer in a large port of entry must deal.

Many other examples of the utility of international law training in a metropolitan practice even where the practitioner is not particularly interested in specializing in the international field could be given. Moreover, this Article has been confined to the professional role of the 
practitioner without any reference to the international law work which so many practitioners have carried on when called into public service or in connection with bar association or foundation activities.

Finally, lawyers are, or should be, leaders in their communities and it is essential that the American people have intelligent and informed leadership in their discussions of our foreign policy. Even if international law training were never put to mundane bread and butter use, though at least as far as a large city practice is concerned this would seem highly unlikely, it will be a source of great personal pleasure and enable the lawyer to play a constructive role in these essential discussions.

The writer hopes that the law student would be encouraged to take an international law course, not as the first step in a highly specialized program, but on the same basis as a course in contracts, trusts and estates or taxation. If he looks forward as an active practitioner to practicing exclusively public international law he may, so far as present experience goes, be doomed to disappointment. But in order to obtain a legal skill of growing utility in the context of the general practice of the law as well as to prepare for that responsible leadership in his community which lawyers are expected to provide, the law student would do well to steal a few hours from Williston, Powell and Griswold for Dickinson, Hudson or Jessup. 